\title{
Editor's Message Hydrogeology education in Germany: what are we missing?
}

\author{
Maria-Theresia Schafmeister, Associate Editor
}

Do you ever take time for leisurely conversations about your profession with "normal" non-scientist friends? Have you ever tried to discuss your field of specialization with children? At the next opportunity, enquire what they understand of (a) microbiology, (b) geology, and (c) hydrogeology. Cultural and educational differences would certainly elicit different responses from people living in various regions of our diverse world, but in Germany, the answers would most likely be: (a) Microbiology is practiced by people who use test tubes, who decipher human genes, clone animals, and discover new therapies; (b) Geology, that is even easier: suntanned men who endure the harsh outdoors, dexterously climbing up hills to gather minerals, find dinosaur bones, and who occasionally discover oil; (c) Hydrogeology - Is that some sort of underwater geology?

We cannot expect the bulk of our population to be versed in all areas of science. Neither can we criticize the media for their partiality in covering fields that have recently made truly impressive advances. But it is still clear that people know too little about the discipline that deals with the occurrence of perhaps the most eminent natural resource and foodstuff: water. The readers of Hydrogeology Journal may not be the most suitable audience to be lectured on the contents of our research field nor on its importance for the well being and socioeconomic functioning of modern societies, but we, - and primarily the university teachers among us - should think a lot more about how we 'sell' hydrogeology to the people.

The process should start with children. In Germany there are no geology courses at the pre-university school levels. Knowledge about volcanoes, plate tectonics, and earth history not only fascinates most children, but could also be used as a stepping-stone to channel their interest

Received: 31 August 2001 / Accepted: 4 September 2001

Published online: 11 September 2001

(C) Springer-Verlag 2001

M.-T. Schafmeister (

Institut für Geologische Wissenschaften, EMAU Greifswald,

F.-L.-Jahn-Str. 17a, 17487 Greifswald, Germany

e-mail: schaf@uni-greifswald.de

Tel.: +49-3834-864592, Fax: +49-3834-864572 into other areas of science. This knowledge is allocated only a few hours a year as part of other disciplines in 13 years of pre-university education. Therefore, when reaching the university level, only a few students make their way into geology. Of those, a majority is attracted by a romantic notion of the life of a geologist, as depicted above, that may even lead to disappointment when they need to focus on the more conceptual - but no less fascinating if properly taught- aspects of our science. The proportion of geology students with respect to students of all natural sciences in Germany varies largely among universities, but overall is barely $10 \%$, compared with $30 \%$ for students of life sciences.

What portion of geology students enters the field of hydrogeology? Exact figures depend on what is meant by "entering the field". In the context of the low enrollment in geology, however, the picture for hydrogeology does not look so bleak, and is perhaps even encouraging. It varies greatly from one university to another and is influenced strongly by the reputation and engagement of workgroups and institutes. In Germany there are at least 24 universities that provide training and education in hydrogeology as an optional sub-discipline of applied geology, which in turn is a required part of the German diploma in geology. At about five universities, applied geology and hydrogeology are represented by more than two chairs, each with their corresponding work staff. The University of Tübingen stands out with five professors in hydrogeology and a variety of subspecialties ranging from tropical hydrogeology to organic hydrogeochemistry. This level of commitment reflects on the students' choice of diploma- (undergraduate) or doctoral theses. At Tübingen, every fourth undergraduate student and every sixth graduate student in geology decides in favor of a hydrogeological thesis. There is another noteworthy trend in many German universities: more and more students enrolled in geophysics, geography, and sometimes even chemistry, are deciding to work in hydrogeology.

This growing interest in our subject by both geologists and non-geologists is likely fuelled in no small degree by concerns for job assurance. It must be remembered that Germany is a relatively small country, lacking major unexploited ore minerals and oil reserves, but with a huge experience in geotechnology as well as a great need to study and prevent environmental hazards. Students in applied geology who can demonstrate proficiency in dealing 
with these problems have the best chances in competing for jobs. The fact that after graduation with a hydrogeological thesis very few students decide to stay at a university for a doctorate reflects their immediate usefulness outside of academia. This is an honor for university teachers but at the same time may be somewhat frustrating when seeking good $\mathrm{PhD}$ students. We still long for more students who would find greater appeal in interesting research topics than in immediate practical applications. That the opposite is, in fact, true may once again reveal our failure to interest students in the basics of our field.

In summary, German educators in hydrogeology are not dealing with a reduction of the job market for stu- dents in our career. Neither are we necessarily dealing with student apathy once they have become familiar with the true nature of what we do. We are dealing, perhaps, with the fact that students "discover" hydrogeology too late, and only then seeing its practical aspects. Readers from other countries may reflect on whether this applies to their part of the world as well. I suspect it does. We can all learn from this state of affairs. We may be competing to get funding for our next research project, or endeavoring to entice our next graduate student to join our group. Maybe what we should be doing is taking a break, and talking to our neighbors and to their children about what science, geology, and hydrogeology are truly about. 